\title{
PLATO ON DEMOCRACY AND EXPERTISE ${ }^{1}$
}

\author{
By R. W. SHARPLES
}

\section{I}

In the Gorgias (463aff.) Plato makes Socrates say to Polus that rhetoric is not a skilled art (technê) at all, but one of a number of occupations collectively described as 'flattery' (kolakeia) and said to be based on experience. The other examples given are sophistry, cosmetics, and cookery. These practices have no understanding of what they do, or as Plato puts it they can give no account of it (465a).

Cooks might well be indignant to be told that there is no skilled art in what they do, and on the face of it Socrates' position seems highly implausible. But Plato's point becomes clearer first from the Gorgias itself, and then by comparison with the Republic. In the Gorgias cookery is repeatedly contrasted with medicine. Both are concerned with food, since diet was an important part of ancient Greek medicine, but while the doctor is concerned with the well-being of the body, the cook is concerned simply with gratifying people's desires. Similarly the rhetorician, or the politician who employs rhetoric, gives the people what gratifies them: in ancient Athens, fortifications, dockyards, an empire, and tribute (519a); nowadays, perhaps, tax cuts. The true politician, of whom Socrates at the end of the dialogue claims to be the only example (521d), is concerned with the wellbeing of the citizen's souls. As Socrates argues shortly after his remarks to Polus concerning cookery, there is a difference between what people think they want and what they actually want, i.e., what is good for them (467-8).

But, we might object, even if we accept the contention of Plato's Socrates that cooks are not at all concerned with people's health, only with gratifying their desires, is there not still a great deal of skill and understanding involved in giving people what they think they want? Plato's answer to that question is, it seems, a negative one; and the reason why becomes clear from the analogy of the Large, Strong Animal in Republic 6. 493a-c. He there likens sophists who call the opinions of the general public 'wisdom' to the keepers of a large and strong animal who think that experience of the creature's behaviour, and of what pleases or displeases it, constitutes a skilled art. He is I think suggesting that if there is no rhyme or reason in the 
creature's desires, if they are totally arbitrary and irrational, there can be no art or understanding involved. All the keepers have to go on is experience of what may or may not have worked in the past; there can be no guarantee of whether it will this time. There can be no rational science of what is intrinsically irrational; and Plato puts public opinion in the latter category. The general populace is the biggest sophist of all, and does more to corrupt the young than any sophist can (Republic 6.492). What matters is reasoned argument rather than majority opinion (Gorgias $471 \mathrm{e}-472 \mathrm{~b}$ ), and what is wrong with rhetoric is that it appeals to the latter. Putting it another way, for Plato an understanding or an attitude is not rational unless it is based on right reasoning and understanding; and since for Plato in the Republic everthing derives what reality it has ultimately from the Form of the Good, right reasoning is understanding of what is good and what is not, in absolute, objective terms.

For us, the idea that something as complex and variable as public opinion can be studied scientifically is not an altogether strange one. We have sophisticated methods of analysis, and we have the ability to make more or less accurate predictions from very small statistical samples, in opinion polls for example. Plato and other ancient thinkers recognised that some sciences, such as mathematics, were more exact than others, such as medicine (Philebus 56b); but we could hardly expect him to be as aware as we are of the possibilities of handling complex and variable data mathematically. The reason why Plato says that there can be no art or science in giving people what they think they want is, indeed, not just that people's beliefs about what they want are complex and fluctuating, but that they do not in his view relate to objective reality. However, the former point may encourage his belief in the latter.

The contrast between cookery and medicine, and between rhetoric for which cookery is the analogy and medicine, pervades the Gorgias. Socrates on trial will be like a doctor competing with a pastry-cook before a jury of children (464d, 521e), though after death the tables will be turned and Callicles will be at a loss in the otherworldly lawcourt as much as Socrates is in this world (526e, with which cf. 523c). Athenian politicians have fed the people on dockyards and revenues, with the result that it is festering and unhealthy (518-19). The wicked should not seek to escape punishment but hand themselves over as if to a doctor for cutting and burning (479a). And Polus should hand himself over to Socrates' argument as if to a doctor (475d).

Rhetoric, Gorgias boasts, will enable the orator to be more persuasive than the expert who has knowledge; even when Socrates points out that 
this applies only when the audience is itself ignorant (459b-c), Gorgias regards the way in which rhetoric removes the need for its practitioner to have expert knowledge in other fields as a commendation rather than the reverse. Not only will the doctor be the rhetorician's slave, but the businessman will turn out to be making money not for himself but for the orator (452e), and presumably for the politician who is the prime user of oratory. The orator will be more persuasive than the doctor (456a). Gorgias does have the decency to add that the orator should not deprive the doctor of his reputation just because he has the power to (456-7); it is such hedging his bets on the relation between rhetoric and morality that turns out to be Gorgias' undoing.

There is, however, a distinction to be drawn between public opinion and those who manipulate it. Open to manipulation though public opinion may be, it may still in fact be the safest judge there is for certain questions. As Renford Bambrough pointed out in his analysis of the ship of state passage in Republic 6, ${ }^{2}$ Plato's analogies with crafts like navigation and medicine beg the question by assuming that political questions can be settled by experts in the same way as can the concerns of these crafts. Perhaps there are questions about political goals which from their very nature are best settled in practice by general discussion and agreement, not by a relatively small group of experts. ${ }^{3}$

\section{II}

Plato, however, does not think so. It is not indeed just, or primarily, democracy that he objects to. In the Gorgias it is Callicles, not Socrates, who describes the ordinary people of Athens as a 'refuse made up of slaves and all sorts of people good for nothing except perhaps for physical labour' (489c). Plato's position, in fact, is not so much anti-democratic as antidespotic, in the sense that he sees nothing of value in accepting a position because it is the view of those who happen to have power and influence. However, in democratic Athens that meant the mass of the people, or rather those who could appeal to the people while, in some cases at least no doubt, privately despising them as does Callicles. Plato does not quite say openly in the Gorgias that he sees the Athenian people as a tyrant; but that he does so is indicated by a comparison of Gorgias $510 \mathrm{~b}-\mathrm{d}$, where Socrates says that the way to gain power in a city ruled by a tyrant is to make yourself like the tyrant, with $513 \mathrm{~b}$, where he says that the way to gain power in Athens is to imitate the Athenian people. Perhaps we are meant to conclude 
that the attitudes of a Callicles, valuing power and gaining the advantage over others above all else, are more conventional and widespread in Athenian society than Callicles himself would like to think. ${ }^{4}$

G. Vlastos, indeed, has argued that the Crito shows that the historical Socrates accepted Athenian democracy, and that even in the Gorgias the emphasis placed by Plato's Socrates on expertise is distanced from apparently similar remarks in Xenophon by concern for the moral wellbeing of every member of society. ${ }^{5}$ But concern for the citizens' moral wellbeing does not in itself constitute democracy. In the Republic too the philosopher-ruler is distinguished from the sort of politician Thrasymachus recognises by the fact that he rules in the interests of others, not of himself; ${ }^{6}$ and even if the Gorgias is not as explicit as the Republic in indicating that the majority of citizens are not the best judges of what will lead to their own well-being, the seeds of the attitudes of the Republic are already present there.

What matters for Plato is that the correct judgements should be reached, and that knowledge should prevail. Thus in the ideal state of the Republic, where the Philosopher Rulers by definition know best, Plato's view is that there is simply no point in consulting anyone else. If the views of others are different from those of the Philosopher Rulers, the experts, they must by definition be worse; if they are the same, they will be less soundly based, and in any case there will be no need to take them into account. The position of the ruler in relation to the ordinary citizen is like that of the doctor in relation to his patient; indeed Plato explicitly says that rulers can lie to their subjects for the subjects' own good, though the subjects must not lie to the rulers, and supports this by the analogy of doctors not telling patients the whole truth about their illnesses (Republic 3. $389 b-c)$.

\section{III}

Plato's arguments, then, are not against democracy as such but against ignorant democracy. He believes that there could be rulers whose understanding of what was good for the state was not just a matter of rhetoric, just a matter of what they said, but was at least as soundly based as that of doctors or navigators, so that they would be accepted as the experts (cf. Republic 6. 500d-e, where Plato seems remarkably sanguine about how readily people will accept having the canvas of society wiped clean). Imagine, then, for a moment, that we could persuade Plato that there could 
be a democracy in which all the citizens were well-informed, and were influenced by reasoned understanding rather than by opinions produced by rhetorical persuasion. ${ }^{8}$ Suppose, in other words, that we could show Plato that principle of the division of labour in the Republic does not and should not apply to 'ruling' in the way that it does to building and weaving (Republic 2. 369d-e). If we could persuade Plato of this, then indeed he would have to admit that his likening in the Gorgias of popular opinion to children's preference for pastry-cooks over doctors does not amount to a criticism of all democracy, but only to a criticism of democracy as he saw and experienced it.

Suppose, then, that we could indeed persuade Plato that there could be a well-informed democracy. Suppose that we could persuade him that he misjudged Athenian democracy, or if not that, at least that we would persuade him that we are now better informed and conduct our democratic politics more rationally. Even so, there is I think nothing to suggest that Plato would actually favour such a ideal democracy over other political systems, unless we could show him that it actually constituted the best way of arriving at correct political decisions. In Politicus 303a-b the rule of the many is the least good of the good constitutions, but the best of the perverted ones, in each case because of its limited effectiveness; a democracy cannot achieve much evil, but that is because, for Plato, it cannot achieve much good either. And Plato in the Republic does not see the consultation and involvement of all citizens in decision-making as something that could have any value in itself. There may indeed be explanation intended to win them over, as at Republic 6.500, or in the preambles to the laws in the Laws, but that is another matter. Being prepared to talk to people and justify one's proposals is not in itself democracy - preferable though it may be to dictatorial decrees. Democracy, after all, has to do with power (kratos). And, even if such explanation is interpreted as the education of the citizens, it is education which is seen by Plato not in terms of the discovery of new insights, but in terms of bringing those educated to see in their turn truths that have already been apprehended by others.

This, I fear, is the way in which education is seen throughout the Republic, and not just for the young. ${ }^{9}$ It is not seen as a matter of engaging in discussion so that new insights may emerge, but of sending the recipients of education through a curriculum laid down in advance to lead to a foreseen end. The Guardians are not to be allowed to engage in dialectical argument before the age of 30 , because the young are too disputatious by nature (539b); and judges should not have any experience of wickedness 
early in life but have learned about it later, as something observed in others but alien to themselves (409a-b). Plato wishes, in other words, to remove the chances of people getting the wrong ideas; and forgets that it was only the experience of first thinking a wrong answer right, and then realising that it was wrong, that made the slave-boy in the Meno ready to persevere till he saw the right answer. It is a sad irony that Plato, in the very book in which he portrays education as a matter of enabling people to see the truth for themselves (Republic 7. 518d; cf. Symposium 175d), can speak of compelling the Rulers to apprehend the Good at fifty years of age (Republic 7. 540a), for all the world as if this were a purely mechanical process. He does allow that the philosopher's apprehension of the Good must be such as to withstand refutation (Republic $7.534 \mathrm{~b}$ ); what he does not seem to envisage is that the debate this involves might lead to new and important insights. ${ }^{10}$

\section{IV}

I am not, let me emphasize, wanting to suggest against Plato that there are no objective truths in ethics or politics, or to make democracy depend upon the rejection of any belief in objective values. What I do want to suggest, following K. R. Popper, ${ }^{11}$ is that history suggests that those who construct rigid intellectual, political or educational systems, in a way that only makes sense if those truths are fully known, are generally deluding themselves. Plato at the time of writing the Republic may not think that he himself has as a matter of actual fact achieved complete political and ethical understanding; he may not even think that his Ideal State would ever be realisable in practice, though this is less clear. ${ }^{12}$ But to the extent that he does not think that complete understanding ever could be achieved in practice, to that extent the construction of a political ideal based on the assumption that it could be is at best misguided and irrelevant, at worst misguided and pernicious. It would surely be more appropriate to build into our discussion of political systems from the outset the assumption that they will have to deal with the world as we actually experience it, the limitations of our understanding included.

The question is whether the extent to which our knowledge is provisional, the extent to which experience shows that the most confident knowledge-claims often turn out to be erroneous, is such that, as Popper argued, political theorists are better occupied, not in identifying where such knowledge is located, ${ }^{13}$ but in ensuring that anyone who claims a 
monopoly of it is subject to reasonable checks. This is certainly not the same as denying the existence of objective truths in such matters; indeed, the very possibility of describing knowledge-claims as erroneous depends on the supposition that there are objective truths. Plato, however, thinks that there can be knowledge of the answers to moral or political questions which is so certain that its possessors are entitled, and indeed morally obliged, to persuade others to hand over the direction of politics to them.

It need not be supposed, either, that a recognition of the limits of our understanding must lead to an inability to act. ${ }^{14}$ That is the complaint about Socrates made by I. F. Stone; ${ }^{15}$ Plato himself may have grown similarly impatient. But recognising our lack of certainty need in practice imply only that political action should be undertaken with due humility and diffidence, that divergent points of view should be taken seriously because they may assist us towards a grasp of the truth, and that doctrinaire attempts by particular groups to restructure the whole of society on the basis of particular dogmas are so likely to be misguided that they are best avoided.

\section{NOTES}

1. This is a revised version of a paper delivered as one of four contributions to a panel on 'Plato in his Community' at the annual meeting of the Classical Association in Oxford on 8th April $1992-$ as it turned out, the day before a General Election (something not irrelevant to the issues in the paper). My thanks are due for comments and advice to the other speakers (Angela Hobbs, Dominic Scott, and Christopher Gill who organized the panel) and to others who participated in discussion during the meeting and after it, especially Lindsay Judson, Christopher Rowe, and Malcolm Schofield. Originally intended as a contribution to a debate, the paper emphasizes one particular view of Plato; but I do not think it misrepresents him.

2. 'Plato's Political Analogies' in his own (ed.), Plato, Popper and Politics (Cambridge, 1967), ch. 12, reprinted in G. Vlastos (ed.), Plato, Vol. II (Garden City, 1971), ch. 3.

3. That judgements are best made by the many is asserted by the democratic speaker Athenagoras at Thucydides 6.39 .1 (whatever Thucydides' own attitude to the democratic argument).

4. Charles Kahn, 'Drama and Dialectic in Plato's Gorgias', Oxford Studies in Ancient Philosophy 1 (1983), pp. 75-121, at 100, rightly emphasizes the divergence between Callicles' involvement in democratic politics and his own personal views. My suggestion is that perhaps Plato saw democracy too as simply the struggle for advantage, contrasting it with the order and harmony he himself desires. It does not follow that Plato's understanding of democracy was correct.

5. 'Socrates and Athenian Democracy', Political Theory 11 (1983), 495-516, especially 506-7; reprinted in M. Burnyeat (ed.), G. Vlastos, Socratic Studies (Cambridge, 1994), and in R. W. Sharples (ed.), Modern Thinkers and Ancient Thinkers: The Stanley Victor Keeling Memorial Lectures 1981-1991 (London, 1993), pp. 66-89, especially 78-80.

6. Cf. also the emphasis on the need for wisdom and temperance in the ruler as the crucial political requirement at Laws $4.712 \mathrm{a}$.

7. Cf. Kahn, op. cit., pp. 100-1. In the Republic the unerring knowledge that gives the Philosopher Rulers their authority is based on the Theory of Forms. In the Gorgias Socrates' attempt to convince Callicles is based, not on appeals to another world to which only philosophers have access, but on a challenge to Callicles' understanding of this world; where Callicles sees competition, the stronger gaining the advantage over the weaker and rightly so, as the law of nature ( $483 \mathrm{~d}$ ), Plato's Socrates in 
this dialogue sees nature as Pythagorean order and harmony (508a). Callicles is not convinced, of course.

8. This understanding, be it noted, would have to be more than the true opinion that the lower class in the Republic achieves under the guidance of the superior understanding of the philosophers; for in Plato's view, as soon as we admit the existence of such a superior class, we remove any justification for consulting the majority of the citizens.

9. It is indeed with the young, especially with the Guardian young, that Books 2 and 3 are concerned. But one can hardly suppose that the education of the ordinary citizens in the Republic is any more open-ended - or if it is, it will only be so because precise accuracy in their opinions is both less attainable and less necessary.

10. If Plato thinks that the Rulers have achieved complete understanding, the possibility of new insights appearing in the dialectical process is indeed logically excluded. (I am grateful to Lindsay Judson for emphasizing this point.) But in that case the Republic seems to have no relevance to any educational context in the world of our experience (see §IV below). It may be that Plato allows that some new insights may be achieved, though not such as to imply significant changes in the overall structure of the state, and not such as to call into question the authority of the Philosopher Rulers. But is he entitled to assume that new insights, if there are any at all, will be so limited in scope?

11. Cf. The Open Society and its Enemies I, Plato (London, 5th ed. 1965), especially pp. 167-8; also 134-5.

12. The key passages are Republic $6.499 \mathrm{c}-\mathrm{e}$ on the one hand and Republic $9.592 \mathrm{a}-\mathrm{b}$ on the other.

13. Popper (above n. 11), pp. 120-1. Aristotle's rather different approach to political theory, emphasizing (as Malcolm Schofield pointed out to me) ruling and being ruled in turn, may be connected with his general lack of epistemological anxieties.

14. I am grateful to Lindsay Judson for raising this question.

15. The Trial of Socrates (London, 1988). Cf. Sharples, 'On Socratic Reasoning and Practical Activity' in H. D. Jocelyn (ed.), Tria Lustra, Festschrifi for fohn Pinsent (Liverpool, forthcoming), pp. $43-52$. 